\title{
Light-controlled calcium signalling in prostate cancer and benign prostatic hyperplasia
}

\author{
Vipin Sharma ${ }^{1}$, Rita Rana ${ }^{1}$, Ruma Baksi ${ }^{1,2}$, Swapnil P. Borse ${ }^{3}$ and Manish Nivsarkar ${ }^{1 *}$
}

\begin{abstract}
Background: Identifying ways to reduce the burden of prostate cancer (Pca) or benign prostatic hyperplasia (BPH) is a top research priority. It is a typical entanglement seen in men which is portrayed by trouble in micturition. It stands as a significant problem in our society. Different molecular biomarker has high potential to treat Pca or BPH but also causes serious side effects during treatment.

Main text: The role of calcium signalling in the alteration of different biomarkers of Pca or BPH is important. Therefore, the photoswitch drugs may hold the potential to rebalance the altered calcium signaling cascade and the biomarker levels. Thereby play a significant role in the management of Pca and BPH. Online literature searches such as PubMed, Web of Science, Scopus, and Google Scholar were carried out. The search terms used for this review were photo-pharmacology, photo-switch drug, photodynamic therapy, calcium signalling, etc. Present treatment of Pca or BPH shows absence of selectivity and explicitness which may additionally result in side effects. The new condition of the calcium flagging may offer promising outcomes in restoring the present issues related with prostate malignancy and BPH treatment.
\end{abstract}

Conclusion: The light-switching calcium channel blockers aim to solve this issue by incorporating photo-switchable calcium channel blockers that may control the signalling pathway related to proliferation and metastasis in prostate cancer without any side effects.

\section{Background}

Chronic inflammatory conditions in benign prostatic hyperplasia (BPH) result in an altered prostatic immune system characterized by tissue damage caused by different inflammatory mediators through multiple molecular pathways $[1,2]$. This condition is commonly associated with elderly patients [1]. Studies have also suggested that prostate cancer is influenced by the same factor. Multiple epidemiological and molecular studies have also concluded that patients with BPH live at a higher risk of developing prostate cancer at the later stages of their lives $[3,4]$. So, there is a need of common therapeutic

\footnotetext{
* Correspondence: manishnivsarkar@gmail.com

'Department of Pharmacology and Toxicology, B. V. Patel Pharmaceutical Education and Research Development (PERD) Centre, Sarkhej-Gandhinagar Highway, Thaltej, Ahmadabad, Gujarat 380054, India

Full list of author information is available at the end of the article
}

approaches to their management [5]. Several prognostic markers are identified that can be further explored to halt the molecular pathways that are involved in the progression of chronic inflammation [6, 7]. Intracellular calcium signalling plays an important role in the regulation of gene expression $[8,9]$. As a result, identification of calcium coupling receptors using molecular targets against Pca or BPH can be potentially useful in the management of these complications [7, 10]. So, it revealed that angiogenesis, metastasis, and tumor initiation and progression are regulated by intracellular $\mathrm{Ca}^{2+}$ homeostasis which is altered in cancer cells [11]. Application of chemotherapy to control these conditions comes with severe side effects affecting the cancer and normal cells simultaneously $[12,13]$. So, the localized place is the promising way to treat cancer cells and prevent cell 
proliferation by targeting $\mathrm{Ca}^{2+}$ signalling $[14,15]$. The mechanisms behind $\mathrm{Ca}^{2+}$ channels/transporters or $\mathrm{Ca}^{2+}$ ATPase pumps are still unclear [16, 17]. In this aspect, the current review is designed to study the role of cellular mechanisms underlying the regulation of $\mathrm{Ca}^{2+}$ signalling in proliferated cells in Pca or BPH. This review also focuses on the novel therapeutic evidence to control the proliferation through $\mathrm{Ca}^{2+}$ channels and intercellular communication in the tissue system [18-20]. Voltagegated calcium channel $\mathrm{Ca}_{\mathrm{v}} 3.2$ can be a potential differential biomarker for survival and treatment response in breast cancer subtypes [21]. Similarly, store-operated calcium entry (SOCE) plays a role in migration and proliferation [22]. Thus, we discuss about the role of different biomarkers linked with calcium signalling cascade and their use as a single therapeutic target and as a light switch in effective management of Pca or BPH.

\section{Objective}

The mechanism of a complex interplay of the inactivation and activation of extracellular and intracellular calcium oscillations on the molecular level in the context of $\mathrm{BPH}$ has not been fully elucidated and can be modified [23]. The experimental possibility of lightresponsive biologically active materials in the therapy are a new domain, but it is difficult to give a rational therapeutic regimen. Most importantly, it requires precise manipulation of the area, dosage time, and concentration of the active form of drug molecules [24]. The caged compounds which are irreversibly activated with light can be modulated as light-sensitive compounds that can be switched between the active and inactive states $[25,26]$. An attempt is made to address the fundamental use of photoswitches and their usefulness in pharmacological applications such as in Pca or BPH [27]. Researchers have studied the calcium oscillation in cells with the help of a photochromic molecule that switched between high and low affinity states. $\mathrm{Ca}^{2+}$ is the most diverse secondary messenger molecule in the cell $[28,29]$, and its levels are responsible for many physiological functions including muscle contraction and various signalling pathways [30,31]. Similarly, several mechanisms are proposed that can regulate $\mathrm{Ca}^{2+}$ homeostasis [32, 33]. The uncontrolled cell proliferation cause disruptions in $\mathrm{Ca}^{2+}$ handling, and that can contribute to the pathogenesis of many diseases [34-36]. There are various inflammatory mediators such as CD19 or CD20, B lymphocytes (10-15\%), macrophages (15\%), and $\mathrm{CD}^{+} \mathrm{T}$ lymphocytes (70-80\%, mostly CD4 are implicated in cases of $\mathrm{Pca}$ or $\mathrm{BPH})$. Chronic inflammation occurs in the prostate tissue due to the involvement of multiple factors including the autoimmune responses [4]. The present review briefly summarizes the latest advances in the development of photo-drug tools that are associated with $\mathrm{Ca}^{2+}$ signalling and their applications in remote cell modulation. Our goal is to provide a general approach to choose biomarkers linked with Pca or $\mathrm{BPH}$ for optical control of $\mathrm{Ca}^{2+}$ signalling, thereby resulting in better spatiotemporal control of drug action via advances in photoswitch technologies. Ultimately, we can expect an enhanced safety and efficacy profile of the photopharmaceutical agents that have lesser side effects compared to other conventional treatment options [37, 38].

\section{Photodynamic therapy for benign prostatic hyperplasia}

Boch et al. has used lemuteporfin as a photosensitizer to kill the cells after its activation at nanomolar concentration. This helped in transurethral photodynamic treatment and remedial consequences for lower urinary tract side effects $[39,40]$. The outcome additionally indicates lemuteporfin photodynamic therapy is a novel treatment approach for men with lower urinary tract symptoms (LUTS) due to BPH [41]. In many cases, laser innovation has been utilized to treat $\mathrm{BPH}$ condition. However, this methodology plays an important role in minimizing the $\mathrm{BPH}$ side effect as transurethral resection of the prostate. Although the laser innovation offers the critical advantages to $\mathrm{BPH}$ patients, further chronic studies warranted to confirm the safety [42].

\section{Promising targets of Pca (prostate cancer) and benign prostatic hyperplasia associated with $\mathrm{Ca}^{2+}$ signalling \\ Androgen receptor}

In the cytoplasm, androgen receptor binds with active form dihydrotestosterone (DHT) and is responsible for the growth of prostate by encoded proteins. Androgen receptor is a major factor for prostate enlargement, due to the imbalance between cell death and proliferation; it is used to treat BPH/LUTS. In the current treatment approaches, the dynamic function of testosterone is hindered by utilizing $5 \alpha$-reductase inhibitors, such as finasteride. Drugs like finasteride inhibit the conversion of testosterone to DHT [43-45]. The nuclear androgen receptor and its proliferation is influenced by androgeninduced calcium signalling pathways leading to disturbances in androgen receptor signalling via T-type $\mathrm{Ca}^{2+}$ channels. This promotes the prostate cell growth and significant morphological and biochemical changes [4648]. Cifuentes et.al revealed that calmodulin ( $\mathrm{CaM})$ has a major role in proliferation in prostate cells so there is a need of CaM antagonist for blocking the AR activity in a wide variety of proliferated cells [49]. For using the photoswitch drug, it has been studied that AR has a role to increase cAMP which is potentiated by glucosestimulated insulin secretion (GSIS) [50] via the mobilization of intracellular $\mathrm{Ca}^{(2+)}$. However, the 
objective of targeting allosteric sites is troublesome. In this way, they have utilized azobenzene determined prearranged positive allosteric modulators (PAMs) structured and tried against the glucagon-like peptide-1 receptor (GLP-1R) movement offering better management [51]. Simultaneously, there is a need for specific switches of calcium channels that are being regulated by androgen receptor which directly inhibits the proliferation of enlarged prostate cells as per the requirement.

\section{Vitamin D receptor (VDR)}

Increasing the expression of $\mathrm{Ca}^{2+}$ pumps is maintained by low $\mathrm{Ca}^{2+}$ levels to maintain vitamin D levels [52]. Calcium channels are regulated by VDR agonist which has immunomodulatory, anti-proliferative, antibacterial, and anti-inflammatory properties and could be an option to treat $\mathrm{BPH}$. Vitamin D increases VDR protein level in all the tissues including prostate. Vitamin D metabolites inhibit the growth of normal and malignant prostate cells and probably act via ligand-dependent stabilization. Apoptosis, differentiation, and cell cycle are directly linked with VDR response elements [53, 54]. Cyclooxygenase-2 articulation and prostaglandin E2 generation in $\mathrm{BPH}$ stromal cells additionally produce an inhibitory impact on the RhoA/ROCK pathway. Vitamin D action at a dose of $6000 \mathrm{IU} /$ day has shown to diminish the increased prostate volume in BPH patients [55-58]. 1,25-Dihydroxyvitamin D3 stimulation has also linked with calcium-associated TRPV6 in proliferation, apoptosis, and resistance providing synergistic effect [59-62]. Lehen'kyi et al. referenced in his article that TRPV6 is firmly controlled by intracellular $\mathrm{Ca}^{2+}$ fixations $\left(\left[\mathrm{Ca}^{2+}\right]_{\mathrm{i}}\right)$ and leads highly calcium-selective currents in prostate cells [63-66]. This allows $\mathrm{Ca}^{2+}$ entry via TRPV6 and thereby promotes antiapoptotic pathways in cancer cells [66]. Considering this, all VDR can be a potential target in drug discovery of new photoswitch drugs.

\section{Alpha (a)-1 receptors}

Due to the rich source of $\alpha 1$ receptors in the prostate gland [67], presently, alpha-1 blocker is utilized for treating BPH conditions by bladder obstruction [68] and interrupts motor sympathetic nerve supply to prostate. Alpha-1 adrenoceptors in human prostatic muscle provide a rationale for using $\alpha$-blockers [69]. Alpha adrenoceptor subtypes interact with $\mathrm{G}$ proteins of the Gq/11 family and activate phosphoinositide turnover and calcium signalling, although with different levels of effectiveness [70]. $\alpha 1$ blockers loosen up the prostate smooth muscle and decline urethral obstruction, at last prompting help in LUTS which is a noteworthy job in the pharmacotherapeutic management of $\mathrm{BPH}$ [69]. We talk about the prospects for the particular conveyance of light to these organs and the particular prerequisites for light-active drugs [71]. Photoswitchable drugs are in the pipeline and identified with ionotropic glutamate receptors; kinate receptors; AMPA receptors; metabotropic glutamate receptors, adrenergic receptors, muscarinic acetylcholine receptors, dopamine, histamine, and serotonin receptors; calcium and potassium channels; and a number of transporters [72]. Thebault et al. revealed that alpha- 1 adrenoceptors are directly regulating the activation of TRP-mediated $\mathrm{Ca}^{2+}$ entry, with all the members of the signalling cascade of $\alpha 1$-adrenoceptors that serve as targets for therapeutic interventions of cell proliferation which is ultimately responsible for the growth of prostate cancer cells $[67,73]$.

\section{$\beta$-adrenoceptor agonists}

Pharmacological apparatuses grew further endeavors to order prostatic $\beta$-adrenoceptors. Human stromal cells and epithelial cells appeared to raise adenylate cyclase by $\beta$-adrenoceptor [74]. Sharma et al. gave the information about coupling the beta-3 adrenoceptor to $\mathrm{K}_{\mathrm{ATP}}$ and $\mathrm{BK}_{\mathrm{Ca}}$ channels initiating the tocolytic impacts, which indicates the powerful trigger of $\beta 3$-adrenoceptors in buffalo myometrium and intervening their impact through ascent in c-AMP [30]. Similarly, $\beta 3$-adrenoceptor mRNA was recognized in human prostatic tissue. Haynes et al. studies show that activation on beta- 3 and beta- 1 adrenoceptor activation is decreasing the $\alpha_{1}$-adrenoceptormediated contractions $[75,76]$. In some clinical studies, it is mentioned that the use of beta blockers by the patient increases the risk of $\mathrm{BPH}$ [77]. The betaadrenoceptor is a $\mathrm{G}(\mathrm{s})$-protein-coupled receptor which significantly increased cAMP in the smooth muscle cell [78]. In the case of a hypertensive patient who took beta blocker, there is more risk to develop $\mathrm{BPH}$ and also potentiate the response of alpha-adrenoceptor which activated the phospholipase $C$. This ultimately formed inositol-1,4,5-trisphosphate $\left(\mathrm{IP}_{3}\right)$ and diacylglycerol (DAG), leading to the activation of myosin light-chain (MLC) kinase by calcium-dependent mechanisms and thereby contraction of the prostatic smooth muscle [75, $76,79]$. For treating the hypertensive patient, we have to be more focused on the development and/or use of beta blockers as photoswitches. This caution is important to avoid the activation of $\alpha_{1}$-adrenoceptor-mediated contractions in the prostate.

\section{C-X-C motif chemokine ligand-5 (CXCL5)}

Studies have demonstrated that the relocation and intrusion of prostate disease cells were significantly influenced by the CXC-type chemokines CXC-12 and CXC5 , in vitro and in vivo [80], while the CXCL5 enacted comparative pathways related to prostate epithelial cell expansion or attack [81, 82]. CXCL5 is involved in carcinogenesis and cancer progression has emerged, and it 
could be used for future role in both diagnosis and cancer therapy $[83,84]$. The fundamental development of CXCL is evoked by calcium signalling. P2X4 antagonist causes inhibition of CXCL5 secretion and is unable to find ways in the absence of extracellular $\mathrm{Ca}^{2+}$ [85]. Actuation of both calcium-activated potassium channels and chloride channels and tweak of L-type voltage-sensitive calcium channels is animated by CCR5. This investigation has been led in a focal sensory system so further examination is ought to be prompted in the Pca or BPH [86-88].

\section{Histone deacetylase (HDAC)}

Photoswitchable histone deacetylase (HDAC) inhibitors are potential antitumor specialists as reported [89]. The protein articulation levels are increased in HDAC1 and DNA methyltransferases (DNMTase) DNMT1 in prostate cancer [90]. Inhibition of HDAC assumes a noteworthy job in chemotherapy and chemoprevention in androgen-subordinate prostate malignant growth and androgen-autonomous prostate disease cells by utilizing $15 \mu \mathrm{M}$ sulforaphane (SFN) in 40, 30, and 40\% in BPH-1, LnCaP, and PC-3 cells, respectively, which propose a novel way to treat prostate malignancy [91]. Varga et.al contemplate and demonstrate that in the upregulation of HDAC inhibitors, protein articulation of $\mathrm{Ca}^{2+}$ pumps in an assortment of breast cancer cell lines uncovered low PMCA4b articulation in the ER- $\alpha$-positive cells. So, we can say that $\mathrm{Ca}^{2+}$ pump levels shape the intracellular $\mathrm{Ca}^{2+}$ signals that influence a few downstream flagging pathways which might be valuable to treat $\mathrm{BPH}$ or prostate cancer [92]. Due to the depletion of ER calcium stores, the advancement of photoswitchable HDAC inhibitors is assumed to have a major role for HDAC inhibitor development with lesser side effects [93].

\section{Transforming growth factor (TGF $\beta 1$ )}

Major inhibitory medications that are right now being grown basically to treat fibrotic malady are summarized [94]. Given the focal job of TGF $\beta 1$ in fibrosis, drugs focusing on TGF $\beta 1$ might be useful for the treatment of fibrosis [43]; however, along with the inflammatory cytokine inhibition of IL-10 and TGF- $\beta$, it shows significant cure rates after PDT [95]. TGF-beta1 induced intracellular $\mathrm{Ca}^{2+}$ signal [96], and it is generally a growth inhibitor of both benign prostatic epithelial cells [97, 98] and prostatic cancer cells [99]. TGF-beta1 treatment brought about abatement in ATP amalgamation and to a depolarization, prompting an arrival of $\mathrm{Ca}^{2+}$ from mitochondria and diminished action of the $\mathrm{Ca}^{2+}$ pumps. Zemfira et al.'s report demonstrates that TGF-b1 is expanded dimensions of calcium levels inside PC-3U cells. The effect was analyzed as being due to an inhibitory effect of TGF-b1 on the mitochondria of the cells [100].
So, we can say that light-delicate calcium channel blockers, calcium $(\mathrm{CaV})$ channels, play pivotal jobs in the age of activity possibilities and in the synaptic transmission and are practical objectives for photopharmacology. Isomerization of the photoswitch with $380 \mathrm{~nm} /$ $500 \mathrm{~nm}$ light abbreviated and stretched, unblocking and obstructing the pore $[27,101]$. So, to control the TGFB1 receptor, we can use the photoregulation procedure by diminishing the prostate growth and malignant growth, with decreasing impacts on another body.

\section{Thromboxane A2}

Jafari et al. [102] uncovered in his investigation on prostate malignant growth that NSAIDs give some level of defensive impact against prostate disease, yet further examination is required. Expanded articulation of thromboxane synthase was found in prostate tumors, and tumor cell motility was weakened by inhibitors of thromboxane synthase. This investigation was attempted to explain how tumor motility is directed by $\mathrm{TxA}_{2}$. Here, we can say that human prostate malignant growth cells express useful receptors for $\mathrm{TxA}_{2}$ (TP) [103, 104]. Moreover, thromboxane $A_{2}$ mediates smooth muscle contraction, and so, this inflammatory biomarker can be used to treat $\mathrm{BPH}$ [105]. $\mathrm{TXA}_{2}$ pathway may be a potential target for PCa prevention/therapy, because it is upregulated in human prostate cancer [104]. The relation between the calcium and thromboxane $\mathrm{A}_{2}$ is also well studied where cyclooxygenase products of $\mathrm{AA}$, i.e., $\mathrm{PGH} 2$ and $\mathrm{TXA}_{2}$, caused mobilization of intraplatelet calcium [106]. The studies show that the absence of $\mathrm{Ca}^{(2+)}$ ATPase inhibitor-sensitive pool is responsible for the formation of $\mathrm{TXA}_{2}$ in the presence of calcium [107]. Kiefmann demonstrated there is increase in cytosolic calcium in the $\mathrm{TXA}_{2}$ receptor expression [108]. So, thromboxane $\mathrm{A}_{2}$ evoked intracellular calcium in vascular smooth muscle cells [109], which indirectly related to prostate enlargement and muscle contraction.

\section{$\mathrm{N}$-methyl-D-aspartate receptor (NMDAr)}

The memantine is a foe of NMDAr which hindered the in vitro development of cell lines, at 5 to $20 \mu \mathrm{g} / \mathrm{ml}$ (23 to $92 \mu \mathrm{M})$ memantine. Past studies demonstrate that $N$ methyl-D-aspartate (NMDA) receptor levels are utilized to balance for hippocampus-related learning and execution on specific memory undertakings in rodents by androgens. Furthermore, the information likewise gives proof to the articulation and action of NMDAr in prostate malignant growth $[110,111]$. NMDA receptors are stimulated by direct depolarization and activated intracellular $\mathrm{Ca}^{2+}$ homeostasis and signalling [112]. Laprell et al. synthesized an azobenzene-triazole-glutamate (ATG) which is a diffusible photochromic glutamate analogue used as a photoswitchable agonist and used for 
various neurological disorders and monitors the function of the synaptic neuron [113, 114]. Apart from that, it will also exacerbate NMDA- $\Delta \mathrm{Ca}^{2+}$ at the system [112]. So, there is a need for the development of antagonist drugs specific for NMDAR which ultimately controls the $\mathrm{Ca}^{2+}$ homeostasis at the site of prostate cells with lower side effects.

\section{Transient receptor potential (TRPM2)}

TRPM2 is a prominent role in prostate cancer by showing inhibitory activity while knocking down TRPM2 by small interfering RNA technique. It is a protein located in the nuclei in cancer cells [115]. The core cells containing TRPM2 proteins are situated in the malignancy cell. Oxidative stress is activated by $\mathrm{Ca}^{2+}$-permeable channel. TRPM2 causes the survival and migration of SCC cancer cells. So, it could be a potential target for selective treatment [116], because inhibiting the nuclear ADP ribosylation of the prostate cancer cells affects the intracellular cell which is associated with the plasma lemma of benign prostate epithelial cells $[6,115]$. While we know that due to deregulation of TRP channels, the $\mathrm{NO}$ availability is decreased in vascular smooth muscle [117]. The prostate cancer cells do not grow when there is a knockdown of the TRPM2 [115]. In the previous literature, novel azobenzene photoswitch were used for the optical control of TRPV1. So, there is a need to develop a strategy to make TRPM2 as one of these compounds which ultimately antagonizes and demonstrates a photoswitchable antagonist and applied in such a way that modulates ion channel activity [118].

\section{TRPM2 testosterone-repressed prostate message-2}

Miyake et al. distributed a movement in both in vitro and in vivo techniques which indicates improved chemosensitivity of TRPM2 in human androgen-autonomous prostate malignant growth of PC-3 cells. TRPM-2 concealment is not exacerbated by prostate development in portion subordinate antisense (AS) oligodeoxynucleotides (ODNs) AS ODN\#2 in PC-3 cells. Thus, 60 to 80\% tumor volumes have been diminished by in vivo organization of antisense (AS) ODN\#2 in addition to either paclitaxel or mitoxantrone. These discoveries recommend that TRPM-2 has a potential to treat prostate disease with AS TRPM-2 ODN in addition to chemotherapeutics for patients [119]. TRPM-2 present in any sort of mammalian cells, so it might be valuable to recognize prostate amplification and utilized as a delicate molecular marker. This item was specifically in light of the fact that its union was not recognized in the typical rodent ventral prostate gland [120]. Typical investigations demonstrate that calcium channel antagonists in the initial $62 \mathrm{~h}$ of castration creating a dying effect on testosterone-repressed prostate message-2 (TRPM-2) cells [121]. That ultimately improving the group of Sertoli cells [122]. Henceforth, clusterin (testosterone-repressed prostate message-2) (TRPM-2) has been utilized as a marker for apoptosis in the prostate, mammary organ, and other strong organs, and clusterin articulation in tissues, for example, the prostate and mammary organ, gives off an impression of being bound to the apoptotic pathway [123]. Kalka et al. demonstrate the involvement of clusterin in PDT-mediated cell death [124] which indicates overexpression of clusterin in the A431 cell line and no difference in clusterin was seen in the apoptosis-safe RIF-1 cells [125]. TRPM2 gene is positively regulated in the castration-induced and shows antiapoptotic property in LNcaP prostate cancer cells [126]; upregulation of TRPM2 is inhibited by calcium channel blocker due to activation of intracellular calcium which further activated endonuclease and support apoptotic pathways and delay progressions in Pca or $\mathrm{BPH}$ [127]. It is reasoned that TRPM2 has a noteworthy relationship with calcium flagging and could be driving a promising focus to treat Pca or BPH exactly.

\section{Discussion}

Here in the review, we discuss the role of calciumassociated biomarkers which could be further useful in the management of Pca or BPH and taken as potential target (Fig. 1) to be controlled by light. Thus, the molecules with anticancer potential with photo-induced calcium signalling and modulation is a new type of treatment to have lesser side effects for the cancer patient and targeted ion channel therapy $[128,129]$. Development of light-sensitive $\mathrm{Ca}^{2+}$ channel blockers and proteins that are involved in $\mathrm{Ca}^{2+}$ signalling $[130,131]$ and its regulation in $\mathrm{Ca}^{2+}$ handling may lead to developing novel therapeutics for cancer [132-134]. All ligandgated receptors such as acetylcholine, glutamate, and GABA receptors have been designed as photoswitchable regulators [135-137]. The photoswitches are also used to investigate neuronal circuit in all optical instruments. Thus, the review discusses the design and the properties and the application of these photoswitches, which can be useful for future perspectives [138-140]. In the previous study, diltiazem (DIL) (non-competitive) and verapamil (VRP) (competitive) inhibitor used as a calcium channel blocker. These drugs cause inhibitory effects of methotrexate (MTX) accumulation through VRP and DIL [141]. Therefore, calcium channel blockers (CCBs) would be used to stop the cancer progression by a complex mechanism in apoptosis [142] since the past examinations recommended that low $\mathrm{Ca}^{2+}$ levels forestall cation-mediated charge balance of DNA, subsequent in the incitement of apoptosis. It promotes apoptosis in both transformed and non-transformed cell models and produces effects of CCBs in $\mathrm{Ca}^{2+}$-dependent and $\mathrm{Ca}^{2+}$ - 


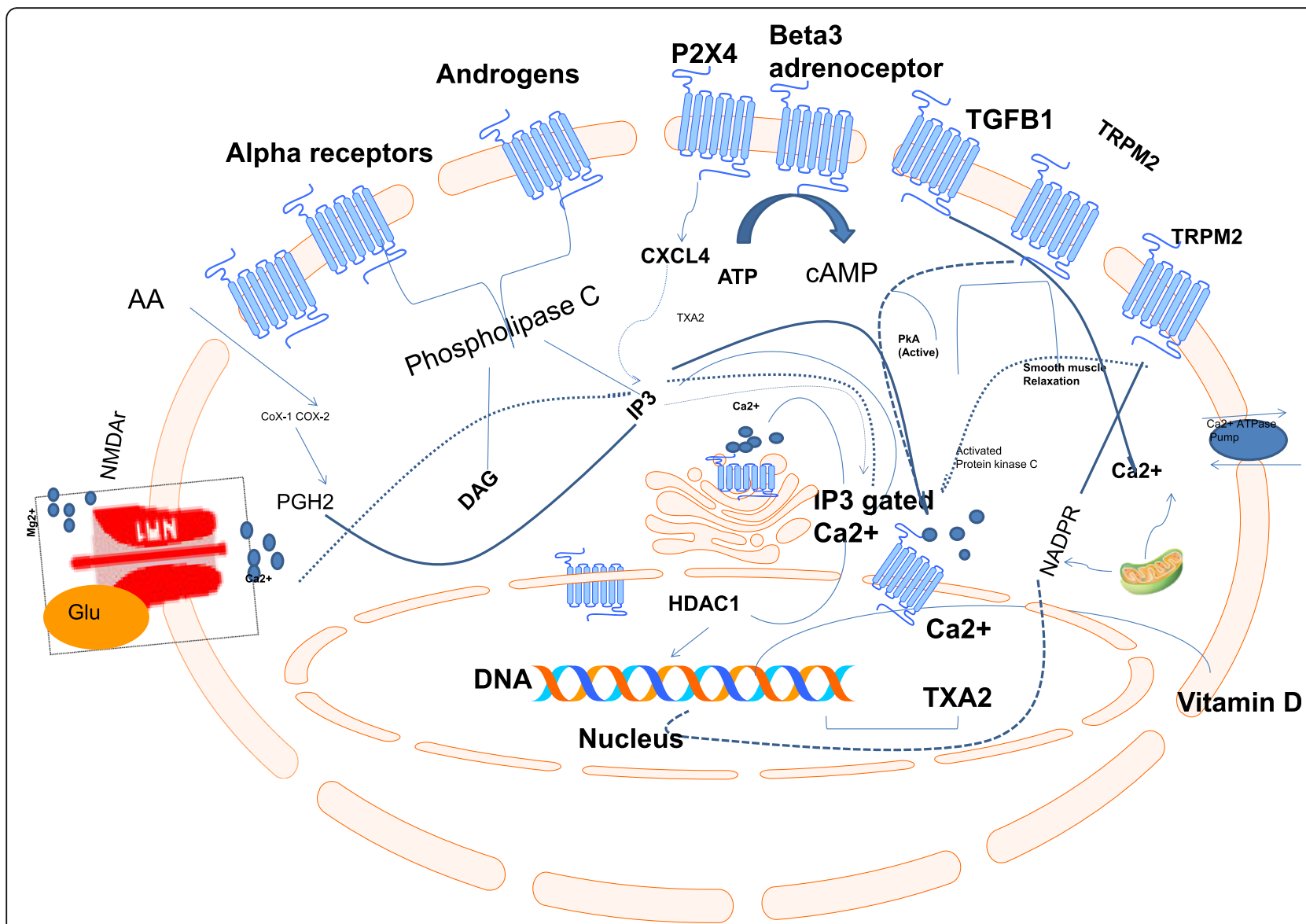

Fig. 1 Regulation of downstream signalling cascade of different biomarkers responsible for prostate cancer or benign prostatic hyperplasia. Ca ${ }^{2+}$ calcium channel; TRPM2 transient receptor potential cation channel, subfamily M, member 2; CAMP cyclin adenine monophosphate; TRP transient receptor potential; TRPV2 transient receptor potential cation channel, subfamily V, member 2; CXCL5 C-X-C motif chemokine ligand-5; HDAC histone deacetylase; DNMTase DNA methyltransferases; TGF $\beta 1$ transforming growth factor; CXCL5 C-X-C motif chemokine ligand-5; DAG diacylglycerol; $I_{3}$ inositol-1,4,5-trisphosphate; VDR vitamin D receptor. Significant stimulation (blue arrow). Partial stimulation (dashed blue arrow)

independent [143-145], so it might be possible that androgen-dependent tissues will be treated by calcium channel agonists for using simultaneous treatment [121]. Mazo et al. clarified in his examinations in regard to the treatment of amiable prostatic hypertrophy (BPH), with helium-neon low-dimension laser treatment (LLLT) in a patient populace of 167 . Twelve to 15 day by day sessions of $20 \mathrm{~min}$ was required, with dosages of 19.0 20.8 J per session. It would be discovered that every treated patient was demonstrated great reaction in prostatic issues. The creator recommends that the positive outcomes ought to energize such a twofold visually impaired preliminary to be set up and that helium-neon low-dimension laser treatment (LLLT) connected transrectally is a legitimate option or adjunctive treatment for the negligibly obtrusive and easy treatment of prostatic issues [146]. This result showed photodynamic therapy indirectly linked with photopharmacology in which we could say that photo-drug therapy consists in treating a patient with a light-sensitive prodrug that is inactivated in the dark after the compound has distributed in the patient and the tumor; light irradiation on the tumor area insures that the light-induced toxicity of the compound is only released at the place of irradiation, i.e., in the tumor or prostate enlargement [95, 147]. So, the anticancer role with photo-induced calcium signalling and modulation is a new type of treatment to reach lower side effects for the BPH or prostate cancer [148] patient and targeted photo-modulate ion channel therapy [37]. The development of light-sensitive $\mathrm{Ca}^{2+}$ channel blockers and proteins that are involved in $\mathrm{Ca}^{2+}$ signalling and its deficiencies in $\mathrm{Ca}^{2+}$ handling may lead to the development of novel therapeutics for cancer [37, 149]. Azobenzene photo-responsive components can be introduced on yielding optical power over the cell capacity, and synapse discharge regulating the channel movement by photo-responsive elements weakens the development of diseased cells, both in vitro and in vivo, which opens another path for pharmaceutical research $[135,150]$. When we design the photoswitch, there will be a 
different scheme for different photoswitches, and it can be prepared by using proteins, drugs, and fatty acids [151]. To prepare the photo-switch using drug and lightresponsive materials, we decided which drug (structure is important here) and photo-switch we have to take and then only we can derive its synthetic route [152]. In the articles, they have used different photo-switches for different proteins and fatty acids [153, 154]. In this case, we can modify the prostate cancer drugs or BPH drugs or fatty acids which act as a biomarker in the photoswitchable form, via targeting the biomarkers that associated with calcium channels, so that it effects in helping and making changes in the localized desired $\mathrm{Ca}^{2+}$ channels to inhibit the proliferation or the metastasis stage of cancer $[155,156]$. Velema et al. delighted in the antimicrobial action of ciprofloxacin photoswitch conjugates and converted it into spirofloxacin, which fundamentally hindered the development rate of microorganisms within the sight of $365 \mathrm{~nm}$, astoundingly, for one of them has a 50-overlap increment in movement contrasted with the first ciprofloxacin. Their antimicrobial action could be constrained by light [157]. Similarly, Hodson et al. showed in his study that light-sensitive drugs could be administered in the form of a pill or activated by irradiating a patch of skin with a blue LED (light-emitting diode). When the light is switched off, the drug flips back into the inactive form, because the active agent is released only where it is required and it gives us a controlled-release form which prevents from hypoglycemic activity [158]. It shows that with the use of light, we can limit the side effects when used to treat Pca or BPH disorder [151]. In other words, azobenzenederived drugs which demand UV light to activate have cytotoxic properties. To overcome this situation, we have to investigate the concentration range of UV range, which helps to shift the wavelength of activation towards red light in the therapeutic window [159].

\section{Conclusion}

The photopharmacology focuses on the tumor or cell multiplication to prevent the metastasis in Pca or BPH. Now the inquiry is emerging why we have to focus on the calcium movement? In light of the fact that despite the side effects, there are biomarkers that cause the cell expansion with the help of calcium stores which eventually give the critical and synergistic advantages. So, there is a need to have focused and balanced medication identified as photoswitches, which can limit the symptoms and target just the abnormal proliferated cells.

\section{Abbreviations}

LED: Light emitting diode; VRP: Verapamil; GABA: Gamma-aminobutyric acid; MTX: Methotrexate; DIL: Diltiazem; CCBs: Calcium-channel blockers; LLLT: Low-level laser therapy; TRPM2: Transient receptor potential cation channel, subfamily M, member 2; TRP: Transient receptor potential;
SCC: Squamous cell carcinoma; TRPV2: Transient receptor potential cation channel, subfamily $\mathrm{V}$, member 2; ODNs: Oligodeoxynucleotides; AS: Antisense; CXCL5: C-X-C motif chemokine ligand-5; HDAC: Histone deacetylase; DNMTase: DNA methyltransferases; TGF $\beta 1$ : Transforming growth factor; SFN: Sulforaphane; PDT: Photodynamic therapy; LUTS: Lower urinary tract symptoms; SOCE: Store-operated calcium entry; CXCL5: C-X-C motif chemokine ligand-5; DAG: Diacylglycerol; MLC: Myosin light chain; $\mathrm{IP}_{3}$ : Inositol-1,4,5-trisphosphate; AMPA: a-Amino-3-hydroxy-5-methyl-4isoxazolepropionic acid receptor; VDR: Vitamin D receptor;

DHT: Dihydrotestosterone; CaM: Calmodulin; CAMP: Cyclic adenosine monophosphate; GSIS: Glucose-stimulated insulin secretion; PAMs: Positive allosteric modulators; GLP-1R: Glucagon-like peptide-1 receptor;

DHT: Dihydrotestosterone

\section{Acknowledgements}

This article is supported by B. V. Patel Pharmaceutical Education and Research Development (PERD) Centre, Ahmedabad, India.

\section{Authors' contributions}

All authors have read and approved the final manuscript. VS participated in the study conception and writing of the manuscript. RR, RB, and SB participated in drafting the manuscript. MN gave the final approval of the version to be submitted and any revised version.

\section{Funding}

The author(s) received no financial support for the publication of this article.

Availability of data and materials

Data and materials are available upon request.

Ethics approval and consent to participate

Not applicable.

Consent for publication

Not applicable

\section{Competing interests}

The authors declare that they have no competing interests.

\section{Author details}

${ }^{1}$ Department of Pharmacology and Toxicology, B. V. Patel Pharmaceutical Education and Research Development (PERD) Centre, Sarkhej-Gandhinagar Highway, Thaltej, Ahmadabad, Gujarat 380054, India. ${ }^{2}$ Faculty of Science, NIRMA University, Sarkhej-Gandhinagar Highway, Ahmedabad, Gujarat 382481, India. ${ }^{3}$ AYUSH Centre of Excellence, Interdisciplinary school of Health Sciences, Centre for Complementary and Integrative Health $(\mathrm{CCIH})$, Savitribai Phule Pune University, Pune, Maharashtra 411007, India.

Received: 28 June 2019 Accepted: 10 June 2020

Published online: 26 June 2020

\section{References}

1. Kramer G, Mitteregger D, Marberger M (2007) Is benign prostatic hyperplasia (BPH) an immune inflammatory disease? Eur Urol 51(5):12021216 https://doi.org/10.1016/j.eururo.2006.12.011

2. De Nunzio C, Presicce F, Tubaro A (2016) Inflammatory mediators in the development and progression of benign prostatic hyperplasia. Nat Rev Urol 13(10):613-626 https://doi.org/10.1038/nrurol.2016.168

3. Miah S, Catto J (2014) BPH and prostate cancer risk. Indian J Urol IJU J Urol Soc India 30(2):214-218 https://doi.org/10.4103/0970-1591.126909

4. De Nunzio C, Kramer G, Marberger M, Montironi R, Nelson W, Schröder F, Sciarra A, Tubaro A (2011) The controversial relationship between benign prostatic hyperplasia and prostate cancer: the role of inflammation. Eur Urol 60(1):106-117 https://doi.org/10.1016/j.eururo.2011.03.055

5. Alcaraz A, Hammerer P, Tubaro A, Schröder FH, Castro R (2009) Is there evidence of a relationship between benign prostatic hyperplasia and prostate cancer? Findings of a literature review. Eur Urol 55(4):864-873 https://doi.org/10.1016/j.eururo.2008.11.011

6. Maly IV, Hofmann WA (2018) Calcium and nuclear signaling in prostate cancer. Int J Mol Sci 19(4) https://doi.org/10.3390/ijms19041237 
7. Wasilenko WJ, Cooper J, Palad AJ, Somers KD, Blackmore PF, Rhim JS, Wright GL, Schellhammer PF (1997) Calcium signaling in prostate cancer cells: evidence for multiple receptors and enhanced sensitivity to bombesin/GRP. Prostate 30(3):167-173 https://doi.org/10.1002/(sici)10970045(19970215)30:3<167::aid-pros4>3.0.co;2-j

8. Ghosh A, Greenberg ME (1995) Calcium signaling in neurons: molecular mechanisms and cellular consequences. Science 268(5208):239-247 https:// doi.org/10.1126/science.7716515

9. Berridge MJ, Bootman MD, Roderick HL (2003) Calcium signalling: dynamics, homeostasis and remodelling. Nat Rev Mol Cell Biol 4(7):517-529 https:// doi.org/10.1038/nrm1155

10. Zhou Y, Gu P, Li J, Li F, Zhu J, Gao P, Zang Y, Wang Y, Shan Y, Yang D (2017) Suppression of STIM1 inhibits the migration and invasion of human prostate cancer cells and is associated with PI3K/Akt signaling inactivation. Oncol Rep 38(5):2629-2636 https://doi.org/10.3892/or.2017.5961

11. Cui C, Merritt R, Fu L, Pan Z (2017) Targeting calcium signaling in cancer therapy. Acta Pharm Sin B 7(1):3-17 https://doi.org/10.1016/j.apsb.2016.11.001

12. Fisher B, Wolmark N, Rockette H, Redmond C, Deutsch M, Wickerham DL, Fisher ER, Caplan R, Jones J, Lerner H (1988) Postoperative adjuvant chemotherapy or radiation therapy for rectal cancer: results from NSABP protocol R-01. J Natl Cancer Inst 80(1):21-29 https://doi.org/10.1093/inci/80.1.21

13. Rastogi $P$, Anderson SJ, Bear HD, Geyer CE, Kahlenberg MS, Robidoux A, Wolmark N (2008) Preoperative chemotherapy: updates of National Surgical Adjuvant Breast and Bowel Project Protocols B-18 and B-27. J Clin Oncol Off J Am Soc Clin Oncol 26(5):778-785 https://doi.org/10. 1200/JCO.2007.15.0235

14. Berridge MJ (1995) Calcium signalling and cell proliferation. BioEssays News Rev. Mol Cell Dev Biol 17(6):491-500 https://doi.org/10.1002/bies.950170605

15. Roderick HL, Cook SJ (2008) Ca2+ signalling checkpoints in cancer: remodelling $\mathrm{Ca} 2+$ for cancer cell proliferation and survival. Nat Rev Cancer 8(5):361-375 https://doi.org/10.1038/nrc2374

16. Michelangeli F, East JM (2011) A diversity of SERCA Ca2+ pump inhibitors. Biochem Soc Trans 39(3):789-797 https://doi.org/10.1042/BST0390789

17. Lipskaia L, Lompré A-M (2004) Alteration in temporal kinetics of Ca2+ signaling and control of growth and proliferation. Biol Cell 96(1):55-68 https://doi.org/10.1016/jbiolcel.2003.11.001

18. Carmeliet P, Jain RK (2000) Angiogenesis in cancer and other diseases. Nature 407(6801):249-257 https://doi.org/10.1038/35025220

19. Sporn MB, Harris ED (1981) Proliferative diseases. Am J Med 70(6):1231-1235 https://doi.org/10.1016/0002-9343(81)90832-9

20. Rayford W, Noble MJ, Austenfeld MA, Weigel J, Mebust WK, Shah GV (1997) Muscarinic cholinergic receptors promote growth of human prostate cancer cells. Prostate 30(3):160-166 https://doi.org/10.1002/(sici)10970045(19970215)30:3<160:aid-pros3>3.0.co;2-q

21. Pera E, Kaemmerer E, Milevskiy M J G, Yapa K T D S, O'Donnell J S, Brown M A, Simpson F, Peters A A, Roberts-Thomson S J, Monteith G R (2016) The voltage gated $\mathrm{Ca}(2+)$-channel Cav3.2 and therapeutic responses in breast cancer. Cancer Cell Int. 16: 24. https://doi.org/10. 1186/s12935-016-0299-0

22. Kappel S, Marques IJ, Zoni E, Stokłosa P, Peinelt C, Mercader N, Kruithof-de Julio M, Borgström A (2017) Store-operated Ca2+ entry as a prostate cancer biomarker-a riddle with perspectives. Curr Mol Biol Rep 3(4):208-217 https://doi.org/10.1007/s40610-017-0072-8

23. Gatlin D M (2013) Improvement of a calcium binding photoswitch through model studies. Retrieved from https:/www.researchgate.net/publication/31 9454150_Improvement_of_a_Calcium_Binding_Photoswitch_Through_ Model_Studies

24. Mayer G, Heckel A (2006) Biologically active molecules with a "light switch.". Angew Chem Int Ed Eng 45(30):4900-4921 https://doi.org/10.1002/anie. 200600387

25. Szymański W, Beierle JM, Kistemaker HAV, Velema WA, Feringa BL (2013) Reversible photocontrol of biological systems by the incorporation of molecular photoswitches. Chem Rev 113(8):6114-6178 https://doi.org/10. 1021/cr300179f

26. Bansal A, Zhang Y (2014) Photocontrolled nanoparticle delivery systems for biomedical applications. Acc Chem Res 47(10): 3052-3060. https://doi.org/ $10.1021 / a r 500217 \mathrm{w}$

27. Hüll K, Morstein J, Trauner D (2018) In Vivo Photopharmacology. Chem Rev 118(21):10710-10747 https://doi.org/10.1021/acs.chemrev.8b00037

28. Hofer AM, Brown EM (2003) Extracellular calcium sensing and signalling. Nat Rev Mol Cell Biol 4(7):530-538 https://doi.org/10.1038/nrm1154
29. Hofer AM, Lefkimmiatis K (2007) Extracellular calcium and cAMP: second messengers as "third messengers"? Physiol Bethesda Md 22:320-327 https:// doi.org/10.1152/physiol.00019.2007

30. Sharma V, Nair SV, Jaitley P, Nakade UP, Sharma A, Choudhury S, Garg SK (2018) ATP-sensitive and maxi potassium channels regulate BRL 37344induced tocolysis in buffaloes-an in vitro study. Theriogenology 107:194202 https://doi.org/10.1016/j.theriogenology.2017.10.044

31. Nair SV, Sharma V, Sharma A, Nakade UP, Jaitley P, Mathesh K, Choudhury S, Garg SK (2017) The functional and molecular studies on involvement of hydrogen sulphide in myometrial activity of non-pregnant buffaloes (Bubalus bubalis). BMC Vet Res 13(1):379 https://doi.org/10.1186/s12917-0171288-9

32. Clapham DE (2007) Calcium signaling. Cell 131(6):1047-1058 https://doi.org/ 10.1016/j.cell.2007.11.028

33. Berridge MJ, Lipp P, Bootman MD (2000) The versatility and universality of calcium signalling. Nat Rev Mol Cell Biol 1(1):11-21 https://doi.org/10.1038/ 35036035

34. Mattson MP (1994) Calcium and neuronal injury in Alzheimer's disease. Contributions of beta-amyloid precursor protein mismetabolism, free radicals, and metabolic compromise. Ann N Y Acad Sci 747:50-76

35. Zong W-X, Thompson CB (2006) Necrotic death as a cell fate. Genes Dev 20(1):1-15 https://doi.org/10.1101/gad.1376506

36. Holt E, Christensen G (1997) Transient Ca2+ overload alters Ca2+ handling in rat cardiomyocytes: effects on shortening and relaxation. Am J Phys 273(2 Pt 2):H573-H582 https://doi.org/10.1152/ajpheart.1997.273.2.H573

37. Ma G, Wen S, He L, Huang Y, Wang Y, Zhou Y (2017) Optogenetic toolkit for precise control of calcium signaling. Cell Calcium 64:36-46 https://doi.org/ 10.1016/j.ceca.2017.01.004

38. Sarma P, Medhi B (2017) Photopharmacology. Indian J Pharm 49(3):221-222 https://doi.org/10.4103/0253-7613.215730

39. Boch R, Canaan AJ, Cho A, Dolphin DD, Hong L, Jain AK, North JR, Richter AM, Smits C, Sternberg ED (2006) Cellular and antitumor activity of a new diethylene glycol benzoporphyrin derivative (lemuteporfin). Photochem Photobiol 82(1):219-224 https://doi.org/10.1562/2005-06-03-RA-564

40. Quinn N J (2005) Lemuteporfin injectable for benign prostatic hyperplasia marketing plan for QLT Inc.

41. Perez-Marrero R, Goldenberg S, Shore N, Benaim E, Fay R, Manyak M, Elhilali M (2005) Transurethral photodynamic therapy (PDT) with lemuteporfin in men with lower urinary tract symptoms (LUTS) due to benign prostatic hyperplasia (BPH): initial clinical experience. Urology 66(3):20

42. Fried NM (2007) New laser treatment approaches for benign prostatic hyperplasia. Curr Urol Rep 8(1):47-52 https://doi.org/10.1007/s11934-0070020-x

43. Gharaee-Kermani M, Macoska JA (2013) Promising molecular targets and biomarkers for male BPH and LUTS. Curr Urol Rep 14(6):628-637 https://doi. org/10.1007/s11934-013-0368-z

44. Rittmaster RS (2008) 5a-reductase inhibitors in benign prostatic hyperplasia and prostate cancer risk reduction. Best Pract Res Clin Endocrinol Metab 22(2):389-402

45. Weisser H, Tunn S, Debus M, Krieg M (1994) 5 alpha-reductase inhibition by finasteride (Proscar) in epithelium and stroma of human benign prostatic hyperplasia. Steroids 59(11):616-620 https://doi.org/10.1016/0039128x(94)90016-7

46. Lyng FM, Jones GR, Rommerts FF (2000) Rapid androgen actions on calcium signaling in rat sertoli cells and two human prostatic cell lines: similar biphasic responses between 1 picomolar and 100 nanomolar concentrations. Biol Reprod 63(3):736-747 https://doi.org/10.1095/ biolreprod63.3.736

47. Zegarra-Moro OL, Schmidt L, Huang H, Tindall DJ (2002) Disruption of androgen receptor function inhibits proliferation of androgen-refractory prostate cancer cells. Cancer Res 62(4):1008-1013

48. Hall M, Todd B, Allen ED Jr, Nguyen N, Kwon Y-J, Nguyen V, Hearne JL, Martin-Caraballo M (2018) Androgen receptor signaling regulates T-type $\mathrm{Ca} 2+$ channel expression and neuroendocrine differentiation in prostate cancer cells. Am. J. Cancer Res 8(4):732

49. Cifuentes E, Mataraza JM, Yoshida BA, Menon M, Sacks DB, Barrack ER, Reddy GP-V (2004) Physical and functional interaction of androgen receptor with calmodulin in prostate cancer cells. Proc Natl Acad Sci U S A 101(2): 464-469 https://doi.org/10.1073/pnas.0307161101

50. Xu W. Ashford F B, Hodson D, Mauvais-Jarvis F (2018) Molecular Mechanism of Androgen Receptor Stimulation of Insulin Secretion in Male B Cells. 
51. Jones BJ, Scopelliti R, Tomas A, Bloom SR, Hodson DJ, Broichhagen J (2017) Potent Prearranged Positive Allosteric Modulators of the Glucagon-like Peptide-1 Receptor. ChemistryOpen 6(4):501-505 https://doi.org/10.1002/ open.201700062

52. Berridge MJ (2016) Vitamin D, reactive oxygen species and calcium signalling in ageing and disease. Philos Trans R Soc Lond Ser B Biol Sci 371(1700) https://doi.org/10.1098/rstb.2015.0434

53. Manchanda PK, Kibler AJ, Zhang M, Ravi J, Bid HK (2012) Vitamin D receptor as a therapeutic target for benign prostatic hyperplasia. Indian J Urol IJU J Urol Soc India 28(4):377-381 https://doi.org/10.4103/0970-1591.105745

54. Samuel S, Sitrin MD (2008) Vitamin D's role in cell proliferation and differentiation. Nutr Rev 66(10 Suppl 2):S116-S124 https://doi.org/10.1111/j. 1753-4887.2008.00094.x

55. Espinosa G, Esposito R, Kazzazi A, Djavan B (2013) Vitamin D and benign prostatic hyperplasia -- a review. Can J Urol 20(4):6820-6825

56. Murphy AB, Nyame YA, Batai K, Kalu R, Khan A, Gogana P et al (2017) Does prostate volume correlate with vitamin $D$ deficiency among men undergoing prostate biopsy? Prostate Cancer Prostatic Dis 20(1):55-60 https://doi.org/10.1038/pcan.2016.41

57. Krishnan AV, Peehl DM, Feldman D (2003) Inhibition of prostate cancer growth by vitamin D: Regulation of target gene expression. J Cell Biochem 88(2):363-371 https://doi.org/10.1002/jcb.10334

58. Manolagas SC, Provvedini DM, Tsoukas CD (1985) Interactions of 1,25dihydroxyvitamin D3 and the immune system. Mol Cell Endocrinol 43(2-3): 113-122 https://doi.org/10.1016/0303-7207(85)90074-7

59. Skryma R, Mariot P, Bourhis XL, Coppenolle FV, Shuba Y, Vanden Abeele F, Legrand G, Humez S, Boilly B, Prevarskaya N (2000) Store depletion and store-operated Ca2+ current in human prostate cancer LNCaP cells: involvement in apoptosis. J Physiol 527(Pt 1):71-83 https://doi.org/10.1111/j. 1469-7793.2000.00071x

60. Burnstein $\mathrm{KL}$ (2005) Regulation of androgen receptor levels: implications for prostate cancer progression and therapy. J Cell Biochem 95(4):657-669 https://doi.org/10.1002/jcb.20460

61. Lehen'kyi V, Raphaël M, Oulidi A, Flourakis M, Khalimonchyk S, Kondratskyi A, Gordienko DV, Mauroy B, Bonnal J-L, Skryma R, Prevarskaya N (2011) TRPV6 determines the effect of vitamin D3 on prostate cancer cell growth. PLoS One 6(2):e16856 https://doi.org/10.1371/journal.pone.0016856

62. Wang T-T, Tavera-Mendoza LE, Laperriere D, Libby E, MacLeod NB, Nagai Y et al (2005) Large-scale in silico and microarray-based identification of direct 1,25-dihydroxyvitamin D3 target genes. Mol Endocrinol Baltim Md 19(11): 2685-2695 https://doi.org/10.1210/me.2005-0106

63. Schindl R, Kahr H, Graz I, Groschner K, Romanin C (2002) Store Depletionactivated CaT1 Currents in Rat Basophilic Leukemia Mast Cells Are Inhibited by 2-Aminoethoxydiphenyl Borate EVIDENCE FOR A REGULATORY COMPONENT THAT CONTROLS ACTIVATION OF BOTH CAT1 AND CRAC (Ca2+ RELEASE-ACTIVATED Ca2+ CHANNEL) CHANNELS. J Biol Chem 277(30):26950-26958

64. Bödding M, Flockerzi V (2004) Ca2+ dependence of the Ca2+-selective TRPV6 channel. J Biol Chem 279(35):36546-36552 https://doi.org/10.1074/ jbc.M404679200

65. Abeele FV, Lemonnier L, Thébault S, Lepage G, Parys JB, Shuba Y, Skryma R, Prevarskaya N (2004) Two types of store-operated Ca2+ channels with different activation modes and molecular origin in LNCaP human prostate cancer epithelial cells. J Biol Chem 279(29):30326-30337

66. Lehen'kyi V, Flourakis M, Skryma R, Prevarskaya N (2007) TRPV6 channel controls prostate cancer cell proliferation via $\mathrm{Ca}(2+) / \mathrm{NFAT}$-dependent pathways. Oncogene 26(52):7380-7385 https://doi.org/10.1038/sj.onc. 1210545

67. Thebault S, Roudbaraki M, Sydorenko V, Shuba Y, Lemonnier L, Slomianny C, Dewailly E, Bonnal J-L, Mauroy B, Skryma R, Prevarskaya N (2003) Alpha1adrenergic receptors activate $\mathrm{Ca}(2+)$-permeable cationic channels in prostate cancer epithelial cells. J Clin Invest 111(11):1691-1701 https://doi. org/10.1172/JCl16293

68. Debruyne FM (2000) Alpha blockers: are all created equal? Urology 56(5 Suppl 1):20-22 https://doi.org/10.1016/s0090-4295(00)00744-5

69. Caine M, Raz S (1975) Some clinical implications of adrenergic receptors in the urinary tract. Arch Surg Chic III 1960 110(3):247-250 https://doi.org/10. 1001/archsurg.1975.01360090017003

70. Schwinn DA, Price DT, Narayan P (2004) alpha1-Adrenoceptor subtype selectivity and lower urinary tract symptoms. Mayo Clin Proc 79(11):14231434 https://doi.org/10.4065/79.11.1423
71. Lerch MM, Hansen MJ, van Dam GM, Szymanski W, Feringa BL (2016) Emerging Targets in Photopharmacology. Angew Chem Int Ed Eng 55(37): 10978-10999 https://doi.org/10.1002/anie.201601931

72. Gazerani $P$ (2017) Shedding light on photo-switchable analgesics for pain. Pain Manag 7(2):71-74 https://doi.org/10.2217/pmt-2016-0039

73. Vanden Abeele F, Skryma R, Shuba Y, Van Coppenolle F, Slomianny C, Roudbaraki M, Mauroy B, Wuytack F, Prevarskaya N (2002) Bcl-2-dependent modulation of $\mathrm{Ca}(2+)$ homeostasis and store-operated channels in prostate cancer cells. Cancer Cell 1(2):169-179 https://doi.org/10.1016/s15356108(02)00034-x

74. Ventura S, Oliver V, White CW, Xie JH, Haynes JM, Exintaris B (2011) Novel drug targets for the pharmacotherapy of benign prostatic hyperplasia (BPH). Br J Pharmacol 163(5):891-907 https://doi.org/10.1111/j.1476-5381.2011. 01332.x

75. Berkowitz DE, Nardone NA, Smiley RM, Price DT, Kreutter DK, Fremeau RT, Schwinn DA (1995) Distribution of beta 3-adrenoceptor mRNA in human tissues. Eur J Pharmacol 289(2):223-228 https://doi.org/10.1016/09224106(95)90098-5

76. Haynes JM, Hill SJ (1997) Beta-adrenoceptor-mediated inhibition of alpha 1adrenoceptor-mediated and field stimulation-induced contractile responses in the prostate of the guinea pig. Br J Pharmacol 122(6):1067-1074 https:// doi.org/10.1038/sj.bjp.0701494

77. Meigs JB, Mohr B, Barry MJ, Collins MM, McKinlay JB (2001) Risk factors for clinical benign prostatic hyperplasia in a community-based population of healthy aging men. J Clin Epidemiol 54(9):935-944 https://doi.org/10.1016/ s0895-4356(01)00351-1

78. Tanaka Y, Horinouchi T, Koike K (2005) New insights into betaadrenoceptors in smooth muscle: distribution of receptor subtypes and molecular mechanisms triggering muscle relaxation. Clin Exp Pharmacol Physiol 32(7):503-514 https://doi.org/10.1111/j.1440-1681.2005.04222.x

79. Andersson K-E, Wein AJ (2004) Pharmacology of the lower urinary tract: basis for current and future treatments of urinary incontinence. Pharmaco Rev 56(4):581-631

80. Begley LA, Kasina S, Mehra R, Adsule S, Admon AJ, Lonigro RJ, Chinnaiyan AM, Macoska JA (2008) CXCL5 promotes prostate cancer progression. Neoplasia N Y N 10(3):244-254 https://doi.org/10.1593/neo.07976

81. Singh S, Singh UP, Grizzle WE, Lillard JW (2004) CXCL12-CXCR4 interactions modulate prostate cancer cell migration, metalloproteinase expression and invasion. Lab Investig 84(12):1666-1676

82. Mochizuki H, Matsubara A, Teishima J, Mutaguchi K, Yasumoto H, Dahiya R, Usui T, Kamiya K (2004) Interaction of ligand-receptor system between stromal-cell-derived factor-1 and CXC chemokine receptor 4 in human prostate cancer: a possible predictor of metastasis. Biochem Biophys Res Commun 320(3):656-663 https://doi.org/10.1016/j.bbrc.2004.06.013

83. Zhou S-L, Dai Z, Zhou Z-J, Wang X-Y, Yang G-H, Wang Z, Huang X-W, Fan J, Zhou J (2012) Overexpression of CXCL5 mediates neutrophil infiltration and indicates poor prognosis for hepatocellular carcinoma. Hepatol Baltim Md 56(6):2242-2254 https://doi.org/10.1002/hep.25907

84. Speetjens FM, Kuppen PJK, Sandel MH, Menon AG, Burg D, van de Velde CJH, Tollenaar RAEM, de Bont HJGM, Nagelkerke JF (2008) Disrupted expression of CXCL5 in colorectal cancer is associated with rapid tumor formation in rats and poor prognosis in patients. Clin Cancer Res Off J Am Assoc Cancer Res 14(8):2276-2284 https://doi.org/10.1158/1078-0432.CCR07-4045

85. Layhadi JA, Turner J, Crossman D, Fountain SJ (2018) ATP Evokes Ca2+ Responses and CXCL5 Secretion via P2X4 Receptor Activation in Human Monocyte-Derived Macrophages. J Immunol Baltim Md 1950 200(3):1159_ 1168 https://doi.org/10.4049/jimmunol.1700965

86. Bajetto A, Bonavia R, Barbero S, Schettini G (2002) Characterization of chemokines and their receptors in the central nervous system: physiopathological implications. J Neurochem 82(6):1311-1329 https://doi. org/10.1046/j.1471-4159.2002.01091.x

87. Hegg CC, Hu S, Peterson PK, Thayer SA (2000) Beta-chemokines and human immunodeficiency virus type-1 proteins evoke intracellular calcium increases in human microglia. Neuroscience 98(1):191-199 https://doi.org/ 10.1016/s0306-4522(00)00101-9

88. Liu QH, Williams DA, McManus C, Baribaud F, Doms RW, Schols D, De Clerca E, Kotlikoff MI, Collman RG, Freedman BD (2000) HIV-1 gp120 and chemokines activate ion channels in primary macrophages through CCR5 and CXCR4 stimulation. Proc Natl Acad Sci U S A 97(9):4832-4837 https:// doi.org/10.1073/pnas.090521697 
89. Szymanski W, Ourailidou ME, Velema WA, Dekker FJ, Feringa BL (2015) Light-controlled histone deacetylase (HDAC) inhibitors: towards photopharmacological chemotherapy. Chem Eur J 21(46):16517-16524

90. Patra SK, Patra A, Dahiya R (2001) Histone deacetylase and DNA methyltransferase in human prostate cancer. Biochem Biophys Res Commun 287(3):705-713 https://doi.org/10.1006/bbrc.2001.5639

91. Myzak MC, Hardin K, Wang R, Dashwood RH, Ho E (2006) Sulforaphane inhibits histone deacetylase activity in BPH-1, LnCaP and PC-3 prostate epithelial cells. Carcinogenesis 27(4):811-819 https://doi.org/10.1093/carcin/ bgi265

92. Varga K, Hollósi A, Pászty K, Hegedūs L, Szakács G, Tímár J, Papp B, Enyedi Á, Padányi $R$ (2018) Expression of calcium pumps is differentially regulated by histone deacetylase inhibitors and estrogen receptor alpha in breast cancer cells. BMC Cancer 18(1):1029 https://doi.org/10.1186/s12885-018-4945-x

93. Jensen H, Andresen L, Pedersen M T, Hansen K A, Skov S (2008) Molecular regulation of MICA expression after HDAC-inhibitor treatment of Jurkat T cells. Presented at the Frontiers in Immunology Research 2008 International Conference.

94. Korbelik M (2006) PDT-associated host response and its role in the therapy outcome. Lasers Surg Med 38(5):500-508 https://doi.org/10.1002/lsm.20337

95. Agostinis P, Berg K, Cengel KA, Foster TH, Girotti AW, Gollnick SO et al (2011) Photodynamic therapy of cancer: an update. CA Cancer J Clin 61(4): 250-281 https://doi.org/10.3322/caac.20114

96. Nesti LJ, Caterson EJ, Wang M, Chang R, Chapovsky F, Hoek JB, Tuan RS (2002) TGF-beta1 calcium signaling increases alpha5 integrin expression in osteoblasts. J Orthop Res Off Publ Orthop Res Soc 20(5):1042-1049 https:// doi.org/10.1016/S0736-0266(02)00020-7

97. Reis STD, Pontes-Júnior J, Antunes AA, de Sousa-Canavez JM, Abe DK, da Cruz JAS et al (2011) Tgf- $\beta 1$ expression as a biomarker of poor prognosis in prostate cancer. Clin Sao Paulo Braz 66(7):1143-1147 https://doi.org/10. 1590/s1807-59322011000700004

98. Sutkowski DM, Fong CJ, Sensibar JA, Rademaker AW, Sherwood ER, Kozlowski JM, Lee C (1992) Interaction of epidermal growth factor and transforming growth factor beta in human prostatic epithelial cells in culture. Prostate 21(2):133-143 https://doi.org/10.1002/pros.2990210206

99. Wilding $\mathrm{G}$ (1991) Response of prostate cancer cells to peptide growth factors: transforming growth factor-beta. Cancer Surv 11:147-163

100. Gizatullina ZZ, Grapengiesser E, Shabalina IG, Nedergaard J, Heldin C-H, Aspenström P (2003) Effect of transforming growth factor-beta on calcium homeostasis in prostate carcinoma cells. Biochem Biophys Res Commun 304(4):643-649 https://doi.org/10.1016/s0006-291x(03)00654-5

101. Schmidt D, Rodat T, Heintze L, Weber J, Horbert R, Girreser U, Raeker T, Bußmann L, Kriegs M, Hartke B, Peifer C (2018) Axitinib: A Photoswitchable Approved Tyrosine Kinase Inhibitor. ChemMedChem 13(22):2415-2426 https://doi.org/10.1002/cmdc.201800531

102. Jafari S, Etminan M, Afshar K (2009) Nonsteroidal anti-inflammatory drugs and prostate cancer: a systematic review of the literature and metaanalysis. Can Urol Assoc J 3(4):323

103. Nie D, Guo Y, Yang D, Tang Y, Chen Y, Wang M-T, Zacharek A, Qiao Y, Che M, Honn KV (2008) Thromboxane A2 receptors in prostate carcinoma: expression and its role in regulating cell motility via small GTPase Rho. Cancer Res 68(1):115-121 https://doi.org/10.1158/0008-5472.CAN-07-1018

104. Dassesse T, de Leval X, de Leval L, Pirotte B, Castronovo V, Waltregny D (2006) Activation of the thromboxane A2 pathway in human prostate cancer correlates with tumor Gleason score and pathologic stage. Eur Urol 50(5): 1021-1031 discussion 1031. https://doi.org/10.1016/j.eururo.2006.01.036

105. Ficarra V, Rossanese M, Zazzara M, Giannarini G, Abbinante M, Bartoletti R, Mirone V, Scaglione F (2014) The role of inflammation in lower urinary tract symptoms (LUTS) due to benign prostatic hyperplasia (BPH) and its potential impact on medical therapy. Curr Urol Rep 15(12):463 https://doi. org/10.1007/s11934-014-0463-9

106. Brace LD, Venton DL, Le Breton GC (1985) Thromboxane A2/prostaglandin H2 mobilizes calcium in human blood platelets. Am J Phys 249(1 Pt 2):H1 H7 https://doi.org/10.1152/ajpheart.1985.249.1.H1

107. Brüne B, Ullrich V (1991) Different calcium pools in human platelets and their role in thromboxane A2 formation. J Biol Chem 266(29):19232-19237

108. Kiefmann M, Bornchen C, Schuster A, Mecklenburg A, Gniech F, Hammerschmidt S, Kiefmann R (2017) S. pneumoniae Induces Endothelial Calcium-Signaling Through Thromboxane A2 Receptor. In B78 ROLE Endothel. CELLS ACUTE LUNG Inj. (pp. A4374-A4374). American Thoracic Society.
109. FitzGerald GA (1991) Mechanisms of platelet activation: thromboxane A2 as an amplifying signal for other agonists. Am J Cardiol 68(7):11B-15B https:// doi.org/10.1016/0002-9149(91)90379-y

110. Beyenburg S, Watzka M, Clusmann H, Blümcke I, Bidlingmaier F, Elger CE, Stoffel-Wagner B (2000) Androgen receptor mRNA expression in the human hippocampus. Neurosci Lett 294(1):25-28 https://doi.org/10.1016/s03043940(00)01542-1

111. Abdul $M$, Hoosein N (2005) N-methyl-D-aspartate receptor in human prostate cancer. J Membr Biol 205(3):125-128 https:/doi.org/10.1007/s00232-005-0777-0

112. Stern JE, Potapenko ES (2013) Enhanced NMDA receptor-mediated intracellular calcium signaling in magnocellular neurosecretory neurons in heart failure rats. Am J Physiol-Regul Integr Comp Physiol 305(4):R414-R422

113. Laprell L, Repak E, Franckevicius V, Hartrampf F, Terhag J, Hollmann M, Sumser M, Rebola N, DiGregorio DA, Trauner D (2015) Optical control of NMDA receptors with a diffusible photoswitch. Nat Commun 6:8076 https:// doi.org/10.1038/ncomms9076

114. Paoletti P, Bellone C, Zhou Q (2013) NMDA receptor subunit diversity: impact on receptor properties, synaptic plasticity and disease. Nat Rev Neurosci 14(6):383-400 https://doi.org/10.1038/nrn3504

115. Zeng X, Sikka SC, Huang L, Sun C, Xu C, Jia D, Abdel-Mageed AB, Pottle JE, Taylor JT, Li M (2010) Novel role for the transient receptor potential channel TRPM2 in prostate cancer cell proliferation. Prostate Cancer Prostatic Dis 13(2):195-201 https://doi.org/10.1038/pcan.2009.55

116. Zhao L-Y, Xu W-L, Xu Z-Q, Qi C, Li Y, Cheng J, Liu L-K, Wu Y-N, Gao J, Ye J-H (2016) The overexpressed functional transient receptor potential channel TRPM2 in oral squamous cell carcinoma. Sci Rep 6:38471 https://doi.org/10. 1038/srep38471

117. Borse SP, Singh DP, Upadhyay D, Sharma V, Nivsarkar MA (2018) Probiotic use in the management of hypertension: A new era of therapeutic management. Indian J Health Sci Biomed Res KLEU 11(3):207

118. Stein M, Breit A, Fehrentz T, Gudermann T, Trauner D (2013) Optical control of TRPV1 channels. Angew Chem Int Ed Eng 52(37):9845-9848 https://doi. org/10.1002/anie.201302530

119. Miyake H, Chi KN, Gleave ME (2000) Antisense TRPM-2 oligodeoxynucleotides chemosensitize human androgen-independent PC-3 prostate cancer cells both in vitro and in vivo. Clin Cancer Res Off J Am Assoc Cancer Res 6(5):1655-1663

120. Buttyan R, Olsson CA, Pintar J, Chang C, Bandyk M, Ng PY, Sawczuk IS (1989) Induction of the TRPM-2 gene in cells undergoing programmed death. Mol Cell Biol 9(8):3473-3481 https://doi.org/10.1128/mcb.9.8.3473

121. Connor J, Sawczuk IS, Benson MC, Tomashefsky P, OToole KM, Olsson CA, Buttyan R (1988) Calcium channel antagonists delay regression of androgen-dependent tissues and suppress gene activity associated with cell death. Prostate 13(2):119-130 https://doi.org/10.1002/pros. 2990130204

122. Liu B, Han MTZ, Zhang J, Lu P, Li J, Song N, Wang Z, Yin C, Zhang W (2013) Downregulation of clusterin expression in human testicular seminoma. Cell Physiol Biochem Int J Exp Cell Physiol Biochem Pharmacol 32(4):1117-1123 https://doi.org/10.1159/000354511

123. Bursch W, Gleeson T, Kleine L, Tenniswood M (1995) Expression of clusterin (testosterone-repressed prostate message-2) mRNA during growth and regeneration of rat liver. Arch Toxicol 69(4):253-258 https://doi.org/10.1007/ s002040050167

124. Kalka K, Ahmad N, Criswell T, Boothman D, Mukhtar H (2000) Up-regulation of clusterin during phthalocyanine 4 photodynamic therapy-mediated apoptosis of tumor cells and ablation of mouse skin tumors. Cancer Res 60(21):5984-5987

125. Nowis D, Makowski M, Stokłosa T, Legat M, Issat T, Gołab J (2005) Direct tumor damage mechanisms of photodynamic therapy. Acta Biochim Pol 52(2):339-352

126. Miyake H, Nelson C, Rennie PS, Gleave ME (2000) Testosterone-repressed prostate message-2 is an antiapoptotic gene involved in progression to androgen independence in prostate cancer. Cancer Res 60(1):170-176

127. Marin MC, Fernandez A, Bick RJ, Brisbay S, Buja LM, Snuggs M, McConkey DJ, von Eschenbach AC, Keating MJ, McDonnell TJ (1996) Apoptosis suppression by bcl-2 is correlated with the regulation of nuclear and cytosolic Ca2+. Oncogene 12(11):2259-2266

128. Barolet D (2018) Photobiomodulation in dermatology: harnessing light from visible to near infrared. Med Res Arch 6(1)

129. Di Corato R, Béalle G, Kolosnjaj-Tabi J, Espinosa A, Clément O, Silva AKA, Ménager C, Wilhelm C (2015) Combining magnetic hyperthermia and 
photodynamic therapy for tumor ablation with photoresponsive magnetic liposomes. ACS Nano 9(3):2904-2916 https://doi.org/10.1021/nn506949t

130. Collot M, Loukou C, Yakovlev AV, Wilms CD, Li D, Evrard A et al (2012) Calcium rubies: a family of red-emitting functionalizable indicators suitable for two-photon Ca2+ imaging. J Am Chem Soc 134(36):14923-14931 https://doi.org/10.1021/ja304018d

131. Mourot A, Fehrentz T, Kienzler M, Tochitsky I, Banghart MR, Trauner D, Kramer RH (2010) Photopharmacology: controlling native voltage-gated ion channels with light. Biophys J 98(3):212a

132. Jiang HN, Li Y, Cui ZJ (2017) Photodynamic physiology - photonanomanipulations in cellular physiology with protein photosensitizers. Front Physiol 8:191 https://doi.org/10.3389/fphys.2017.00191

133. Rennhack A, Grahn E, Kaupp UB, Berger TK (2017) Photocontrol of the Hv1 proton channel. ACS Chem Biol 12(12):2952-2957 https://doi.org/10.1021/ acschembio.7b00523

134. Kienzler MA, Reiner A, Trautman E, Yoo S, Trauner D, Isacoff EY (2013) A redshifted, fast-relaxing azobenzene photoswitch for visible light control of an ionotropic glutamate receptor. J Am Chem Soc 135(47):17683-17686 https://doi.org/10.1021/ja408104w

135. Dong M, Babalhavaeji A, Samanta S, Beharry AA, Woolley GA (2015) Redshifting azobenzene photoswitches for in vivo use. Acc Chem Res 48(10): 2662-2670 https://doi.org/10.1021/acs.accounts.5b00270

136. Lin W-C, Kramer RH (2018) Light-switchable ion channels and receptors for optogenetic interrogation of neuronal signaling. Bioconjug Chem 29(4):861869 https://doi.org/10.1021/acs.bioconjchem.7b00803

137. Kramer RH, Mourot A, Adesnik H (2013) Optogenetic pharmacology for control of native neuronal signaling proteins. Nat Neurosci 16(7):816-823 https://doi.org/10.1038/nn.3424

138. Broichhagen J, Frank JA, Trauner D (2015) A roadmap to success in photopharmacology. Acc Chem Res 48(7):1947-1960 https://doi.org/10. 1021/acs.accounts.5b00129

139. Reiner A, Levitz J, Isacoff EY (2015) Controlling ionotropic and metabotropic glutamate receptors with light: principles and potential. Curr Opin Pharmacol 20:135-143 https://doi.org/10.1016/j.coph.2014.12.008

140. Bregestovski P, Maleeva G, Gorostiza P (2018) Light-induced regulation of ligand-gated channel activity. Br J Pharmacol 175(11):1892-1902 https://doi. org/10.1111/bph.14022

141. Smeland E, Bremnes RM, Fuskevag OM, Aarbakke J (1995) The effect of calcium channel blockers and calcium on methotrexate accumulation in rat hepatocytes. Anticancer Res 15(4):1221-1225

142. Mason RP (1999) Calcium channel blockers, apoptosis and cancer: is there a biologic relationship? J Am Coll Cardiol 34(7):1857-1866 https://doi.org/10. 1016/s0735-1097(99)00447-7

143. Kondo S, Yin D, Morimura T, Takeuchi J (1995) Combination therapy with cisplatin and nifedipine inducing apoptosis in multidrug-resistant human glioblastoma cells. J Neurosurg 82(3):469-474 https://doi.org/10.3171/jns. 1995.82.3.0469

144. Leszczynski D, Zhao Y, Luokkamäki M, Foegh ML (1994) Apoptosis of vascular smooth muscle cells. Protein kinase $\mathrm{C}$ and oncoprotein $\mathrm{BCl}-2$ are involved in regulation of apoptosis in non-transformed rat vascular smooth muscle cells. Am J Pathol 145(6):1265-1270

145. Balakumaran A, Campbell GA, Moslen MT (1996) Calcium channel blockers induce thymic apoptosis in vivo in rats. Toxicol Appl Pharmacol 139(1):122127 https://doi.org/10.1006/taap.1996.0150

146. Mazo V (1994) Transrectal low level laser therapy in the management of prostatic problems. Laser Ther 6(4):203-207

147. Zharov V P, Latyshev A S, Leviev D O (1999) Photomedicine with laser drug delivery technologies. (Vol. 3829, pp. 141-154). Presented at the ALT'98 Selected Papers on Novel Laser Methods in Medicine and Biology, International Society for Optics and Photonics.

148. Ishii T, Sato K, Kakumoto T, Miura S, Touhara K, Takeuchi S, Nakata T (2015) Light generation of intracellular $\mathrm{Ca}(2+)$ signals by a genetically encoded protein BACCS. Nat Commun 6:8021 https://doi.org/10.1038/ncomms9021

149. Sato M, Asano T, Hosomichi J, Ono T, Nakata T (2018) Optogenetic manipulation of intracellular calcium by BACCS promotes differentiation of MC3T3-E1 cells. Biochem Biophys Res Commun 506(3):716-722

150. Broichhagen J, Frank JA, Johnston NR, Mitchell RK, Šmid K, Marchetti P, Bugliani M, Rutter GA, Trauner D, Hodson DJ (2015) A red-shifted photochromic sulfonylurea for the remote control of pancreatic beta cell function. Chem Commun (Camb) 51(27):6018-6021 https://doi.org/10.1039/ c5cc01224d
151. Mourot A, Herold C, Kienzler MA, Kramer RH (2018) Understanding and improving photo-control of ion channels in nociceptors with azobenzene photo-switches. Br J Pharmacol 175(12):2296-2311 https://doi.org/10.1111/ bph.13923

152. Vapaavuori J, Goulet-Hanssens A, Heikkinen IT, Barrett CJ, Priimagi A (2014) Are two azo groups better than one? Investigating the photoresponse of polymer-bisazobenzene complexes. Chem Mater 26(17):5089-5096

153. Samuel BS, Shaito A, Motoike T, Rey FE, Backhed F, Manchester JK, Hammer RE, Williams SC, Crowley J, Yanagisawa M, Gordon JI (2008) Effects of the gut microbiota on host adiposity are modulated by the short-chain fattyacid binding G protein-coupled receptor, Gpr41. Proc Natl Acad Sci U S A 105(43):16767-16772 https://doi.org/10.1073/pnas.0808567105

154. Frank JA, Moroni M, Moshourab R, Sumser M, Lewin GR, Trauner D (2015) Photoswitchable fatty acids enable optical control of TRPV1. Nat Commun 6:7118 https://doi.org/10.1038/ncomms8118

155. Qu Z, Yao W, Yao R, Liu X, Yu K, Hartzell C (2014) The Ca(2+)-activated Cl(-) channel, ANO1 (TMEM16A), is a double-edged sword in cell proliferation and tumorigenesis. Cancer Med 3(3):453-461 https://doi.org/10.1002/cam4.232

156. Cristofanilli M, Charnsangavej C, Hortobagyi GN (2002) Angiogenesis modulation in cancer research: novel clinical approaches. Nat Rev Drug Discov 1(6):415-426 https://doi.org/10.1038/nrd819

157. Velema WA, Hansen MJ, Lerch MM, Driessen AJM, Szymanski W, Feringa BL (2015) Ciprofloxacin-photoswitch conjugates: a facile strategy for photopharmacology. Bioconjug Chem 26(12):2592-2597 https://doi.org/10. 1021/acs.bioconjchem.5b00591

158. Broichhagen J, Podewin T, Meyer-Berg $H$, von Ohlen $Y$, Johnston NR, Jones BJ, Bloom SR, Rutter GA, Hoffmann-Röder A, Hodson DJ, Trauner D (2015) Optical control of insulin secretion using an incretin switch. Angew Chem Int Ed Eng 54(51):15565-15569 https://doi.org/10.1002/anie.201506384

159. Wegener M, Hansen MJ, Driessen AJM, Szymanski W, Feringa BL (2017) Photocontrol of antibacterial activity: shifting from UV to red light activation. J Am Chem Soc 139(49):17979-17986 https://doi.org/10.1021/ jacs.7b09281

\section{Publisher's Note}

Springer Nature remains neutral with regard to jurisdictional claims in published maps and institutional affiliations.

\section{Submit your manuscript to a SpringerOpen ${ }^{\circ}$ journal and benefit from:}

- Convenient online submission

- Rigorous peer review

- Open access: articles freely available online

- High visibility within the field

- Retaining the copyright to your article

Submit your next manuscript at $>$ springeropen.com 